\title{
Molecular detection of some virulence genes in salmonella spp isolated from food samples in Lagos, Nigeria
}

\author{
Stella Ifeanyi Smith ${ }^{1, ~ *, ~ M u i n a h ~ A d e n i k e ~ F o w o r a ~}{ }^{1}$, Adedamilola Atiba ${ }^{2}$, Joseph Anejo-Okopi ${ }^{3}$, \\ Tina Fingesi ${ }^{2}$, Mary Ehi Adamu ${ }^{2}$, Emmanuel Adedayo Omonigbehin ${ }^{1}$, Margaret Iteun Ugo-Ijeh ${ }^{1}$, \\ Moses Bamidele ${ }^{2}$, Peter Odeigah ${ }^{2}$ \\ ${ }^{1}$ Molecular Biology and Biotechnology division, Nigerian Institute of Medical Research Yaba, Lagos, Nigeria \\ ${ }^{2}$ Cell Biology and Genetics department, University of Lagos, Akoka, Lagos, Nigeria \\ ${ }^{3}$ Microbiology department, University of Jos/Jos University Teaching Hospital, AIDS Prevention Initiative in Nigeria department, Jos, \\ Nigeria
}

\section{Email address: \\ stellaismith@yahoo.com (S. I. Smith)}

\section{To cite this article:}

Stella Ifeanyi Smith, Muinah Adenike Fowora, Adedamilola Tiba, Joseph Anejo-Okopi, Tina Fingesi, Mary Ehi Adamu, Emmanuel Adedayo Omonigbehin, Margaret Iteun Ugo-Ijeh, Moses Bamidele, Peter Odeigah. Molecular Detection of Some Virulence Genes in Salmonella Spp Isolated from Food Samples in Lagos, Nigeria. Animal and Veterinary Sciences. Vol. 3, No. 1, 2015, pp. 22-27.

doi: 10.11648/j.avs.20150301.15

\begin{abstract}
Food-borne salmonellosis is the most prevalent disease and major source of Salmonella spp in humans and its detection particularly in developing countries is quite cumbersome and time consuming. Molecular methods for its detection as well as the genotypic diversity of some of the genes responsible for Salmonella virulence are necessary. The aim of the study was to screen for Salmonella spp using the 16S rRNA, to determine whether the invA gene is specific for Salmonella detection as well as virulence genotyping of some genes present in Salmonella $s p p(i n v \mathrm{~A}, s i t \mathrm{C}$ and $s p v \mathrm{~A}, s p v \mathrm{~B}$ and $s p v \mathrm{C})$ from food samples in Lagos, Nigeria. All 76 isolates tested positive for 16S rRNA gene while $53(69.7 \%)$ were positive for salm 3 and salm4 (389 bp) gene. PCR analysis of the invA gene (284bp) showed that $73(96.1 \%)$ were positive, $38(50 \%)$ of the isolates were positive for $s i t \mathrm{C}$ gene while none were positive for $s p v \mathrm{~A}$ and $s p v \mathrm{~B}$ and with the multiplex $-\mathrm{PCR}$ of $i n v \mathrm{~A} / s p v \mathrm{C}$ gene 25 $(33 \%)$ were positive for invA (244 bp) gene and none positive for $s p v \mathrm{C}$ gene. The use of invA gene for Salmonella detection in our food samples is recommended however for most of our isolates the virulence genes were not detected.
\end{abstract}

Keywords: Detection, Food Samples, PCR, Salmonella, Virulence Genes

\section{Introduction}

Salmonella spp are bacteria that cause salmonellosis, and are also common causes of human foodborne outbreaks and diseases in developed and developing countries with attendant public health problem $(1,2)$. Salmonellosis affects 1.3 billion people worldwide each year with an estimated 3 million annual deaths from non-typhoidal salmonelloses (NTS) (3). The disease outcomes is due to exposure to Salmonella spp which ranged from mild symptoms to severe disease cases and sometimes fatal. Salmonella spp are carried by a range of domestic animals including birds and some wild animals. Salmonella spp have been widely isolated from raw meats, poultry and poultry products, milk and milk products and the enviroment (4),In addition outbreaks have also been associated with poor cooking, reheating of foods, and improper handling of food by food preparers. Representing 30.4\% of all Salmonella strains isolated from humans, Salmonella enterica serotype Typhimurium was the second most commonly isolated Salmonella serotype in the Republic of Ireland (5).

Although Salmonella gastroenteritis is generally a selflimiting illness, severe cases may require antimicrobial therapy. Food contamination with antibiotic-resistant bacteria can be a major threat to public health, as the antibiotic resistance determinants can be transferred to other pathogenic bacteria, potentially compromising the treatment of severe bacterial infections. The prevalence of antimicrobial resistance among foodborne pathogens has increased during recent decades (6). This increase is attributed to the selection pressure created by using antimicrobials in food-producing animals, in addition to the 
unregulated use of antibiotics by humans in developing countries (7). The pathogenicity of NTS is attributed to identified virulence genes which has an association with antibiotic resistance (8).

In developing countries poor sanitary conditions appear to be the main risk factor for the transmission of Salmonella spp (9). Majority of Nigerians live below poverty level and patronize low cost foods such as those sold in bukas. However, the hygiene conditions of those bukas are not near standard hygiene practices, and this facilitates transmission of NTS infections among the food consumers. The conventional cultural method of detection of Salmonella in food is problematic, cumbersome and time consuming. To overcome this problem, molecular based PCR technique which is rapid, specific and more sensitive has been developed $(10,11)$. The use of amplification of DNA by PCR method is a revolutionary tool in diagnosis of pathogenic organisms $(12,11)$. Several virulence genes which are target genes for PCR amplification of Salmonella species including $i n v A$, sitC, $s p v \mathrm{~A}, s p v \mathrm{~B}$ and $s p v C$, have been used to detect as well as screen for genotypic virulence in Salmonella isolates from environmental and food samples $(13,8)$. Information on the use of PCR target genes to identifity the NTS from foods and food samples is lacking in Nigeria. The study is aimed at using PCR invA virulenes genes to confirm the presence of Salmonella spp isolated from food samples as well as to screen our local isolates for some of the virulence genes (sitC and $s p v \mathrm{~A}, s p v$ Band $s p v \mathrm{C})$.

\section{Materials and Methods}

A total of 189 isolates suspected to be Salmonella spp (from previous work on the identification of Salmonella from food samples using the REVEAL Kit (Neogen Corp. US), were cultured from meat samples on Salmonella-Shigella agar for 24 hours and pure colonies were obtained and identified using biochemical test as earlier described (4).

\subsection{DNA Extraction}

From the isolates, DNA was extracted by the boiling method and briefly, $1.5 \mathrm{ml}$ of the sample in broth was centrifuged at 10,000rpm for 5 minutes. The supernatant was discarded and the pellets were washed twice with sterile water. After this, $200 \mu$ of sterile water was added to the pellets, the pellets were vortexed to homogenize and boiled in a dry bath at $100^{\circ} \mathrm{C}$ for 10 minutes. This was followed by vortexing and centrifugation at 12,000rpm for 5 minutes. The supernatant containing the DNA was transferred to another tube and stored at $-20^{\circ} \mathrm{C}$. The concentration and purity of the extracted DNA was estimated using a Nanodrop spectrophotometer.

\subsection{DNA Primers}

The primers consist of 16S rRNA (574 bp), salm 3 and salm 4 (389 bp), invA gene (284 bp), sitC (768 bp), spvA $(604 \mathrm{bp})$ and $s p v \mathrm{~B}(1063 \mathrm{bp})$ and multiplex PCR (invA/spvC gene: $244 \mathrm{bp}$ and $571 \mathrm{bp}$ ). The primer sequences and their corresponding genes are shown in Table 1.

\subsection{DNA Amplification}

The reaction for all the PCR was carried out in a $25 \mu 1$ reaction mixture containing 1x PCR buffer (Promega, UK), $1.5 \mathrm{mM}$ Magnesium Chloride, $200 \mu \mathrm{M}$ of each dNTP, 20pMol of each primer, 1.25U Taq DNA polymerase (Promega, UK). The DNA was diluted to give a final concentration of between 10- 200ng/ $\mu \mathrm{l}$ and $1 \mu \mathrm{l}$ of this was used in the PCR and the amplification was carried out in an Eppendorf Mastercycler Gradient (Eppendorf, Hamburg). The 16S rRNA gene, the PCR conditions were 3 min at $95^{\circ} \mathrm{C}$, followed by 30 cycles of $30 \mathrm{~s}$ at $95^{\circ} \mathrm{C}, 30 \mathrm{~s}$ at $54.1^{\circ} \mathrm{C}$ and $1 \mathrm{~min}$ at $72^{\circ} \mathrm{C}$ and final extension for $10 \mathrm{~min}$ at $72^{\circ} \mathrm{C}$. For the salm 3 and salm 4 primer, the PCR conditions were initial denaturation of $5 \mathrm{~min}$ at $95^{\circ} \mathrm{C}$, followed by 35 cycles of $1 \mathrm{~min}$ at $95^{\circ} \mathrm{C}, 1 \mathrm{~min}$ at $65^{\circ} \mathrm{C}$ and 1.5 min at $72^{\circ} \mathrm{C}$ and final extension $10 \mathrm{~min}$ at $72^{\circ} \mathrm{C}$. The invA gene, the PCR conditions were initial denaturation of $1 \mathrm{~min}$ at $95^{\circ} \mathrm{C}$, followed by 35 cycles of $1 \mathrm{~min}$ at $94^{\circ} \mathrm{C}, 1 \mathrm{~min}$ at $56^{\circ} \mathrm{C}$ and $1 \mathrm{~min}$ at $72^{\circ} \mathrm{C}$ and final extension of $10 \mathrm{~min}$ at $72^{\circ} \mathrm{C}$. The results of the two invA gene primers (salm 3 and $\operatorname{salm} 4$, with invA) were tested using the Chi-square analysis (one-tailed) as well as checking for the positive predictive value (PPV), negative predictive value (NPV), sensitivity and specificity with culture as the gold standard. The idea was to actually predict the best invA gene that could be used to detect Salmonella species from our food samples. AS for the sitC primer, the PCR conditions were $3 \mathrm{~min}$ at $94^{\circ} \mathrm{C}$, followed by 30 cycles of 2 min at $94^{\circ} \mathrm{C}, 1 \mathrm{~min}$ at $55^{\circ} \mathrm{C}$ and extension for $1 \mathrm{~min}$ at $72^{\circ} \mathrm{C}$ for $1 \mathrm{~min}$ and final extension for $5 \mathrm{~min}$ at $72^{\circ} \mathrm{C}$. As for the multiplex PCR $(i n v \mathrm{~A} / s p v \mathrm{C})$ primer, the $\mathrm{PCR}$ conditions were $1 \mathrm{~min}$ at $94{ }^{\circ} \mathrm{C}$, followed by 30 cycles of $30 \mathrm{~s}$ at $94{ }^{\circ} \mathrm{C}, 30 \mathrm{~s}$ at $56{ }^{\circ} \mathrm{C}, 2 \mathrm{~min}$ at $72^{\circ} \mathrm{C}$ and final extension of 10 min at $72^{\circ} \mathrm{C}$. The PCR conditions for the $s p v \mathrm{~A}$ and $s p v \mathrm{~B}$ primers were; $5 \mathrm{~min}$ at $94^{\circ} \mathrm{C}$ followed by 30 cycles of $30 \mathrm{~s}$ at $94^{\circ} \mathrm{C}, 30 \mathrm{~s}$ at $60^{\circ} \mathrm{C}, 1 \mathrm{~min}$ at $72^{\circ} \mathrm{C}$ and then a final extension for $5 \mathrm{~min}$ at $72^{\circ} \mathrm{C}$. The PCR products were separated on a $1.5 \%$ agarose gel at 80 Volts and 50bp DNA ladder was used as molecular weight marker. The primer sequences and their corresponding genes are shown in Table 1.

\section{Results}

Only $76(40.2 \%)$ of the 189 isolates were confirmed to be Salmonella spp using biochemical testing, out of these 53 $(69.7 \%)$ of the isolates were confirmed as Salmonella spp using the salm3and salm4 primer set (Fig1). A total of 73 (96.1\%) of the isolates were confirmed to be Salmonella spp using the invA primer set (Fig 2). Table 2 shows a comparison between the sensitivity, specificity, positive and negative predictive values of invAF and invAR with salm 3 and salm 4 primer sets. Chi square analysis between the two primers show there is statistical significance with a $p$-value of $0.019, \mathrm{P}<0.05$. Fig 3 shows the PCR amplification of $16 \mathrm{~S}$ rRNA Salmonella spp. A total of $38(50 \%)$ isolates were positive for the sitC gene (Fig 4) while the multiplex PCR of 
invA/spvC genes showed that only 25(33\%) were positive for the invA gene and none was positive for the $s p v \mathrm{C}$ gene.

Table 1. Primer sequences and their corresponding genes

\begin{tabular}{|c|c|c|c|}
\hline Primer & Target gene & Sequence & Amplified fragment size (bp) \\
\hline 16S rRNA & Genus specific & $\begin{array}{l}\text { 5'-TGT TGT GGT TAA TAA CCG CA -3' } \\
\text { 5'-CAC AAA TCC ATC TCT GGA -3' }\end{array}$ & 571 \\
\hline Salm3/salm4 & invA & $\begin{array}{l}\text { 5'-GCTGCGCGCGAACGGCGAAG-3' } \\
\text { 5'-TCCCGCCAGAGTTCCCATT-3 }\end{array}$ & 389 \\
\hline InvF/invAR & invA & $\begin{array}{l}\text { 5' -ACA GTG CTC GTT TAC GAC CTG AAT -3' } \\
\text { 5' -AGA CGA CTG GTA CTG ATC GAT AAT-3' }\end{array}$ & 284 \\
\hline SitC 3', & $\operatorname{sit} \mathrm{C}$ & $\begin{array}{l}\text { 5'-CAG TAT ATG CTC AAC GCG ATG TGG GTC TCC- } \\
\text { 5'- CGG GGC GAA AAT AAA GGC TGT GAT GAA C-3' }\end{array}$ & 578 \\
\hline spvA & $s p v \mathrm{~A}$ & $\begin{array}{l}\text { 5'-GTC AGA CCC GTA AAC AGT-3' } \\
\text { 5'-GCA CGC AGA GTA CCC GCA-3' }\end{array}$ & 604 \\
\hline spvB & $\mathrm{s} p v \mathrm{~B}$ & $\begin{array}{l}\text { 5'- ACG CCT CAG CGA TCC GCA -3, } \\
\text { 5'- GTA CAA CAT CTC CGA GTA -3' }\end{array}$ & 1063 \\
\hline \multicolumn{4}{|l|}{ Multiplex } \\
\hline 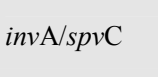 & & $\begin{array}{l}\text { 5'-ACA GTG CTC GTT TAC GAC CTG AAT-3' } \\
\text { 5'-AGA CGA CTG GTA CTG ATC TAT -3' }\end{array}$ & 244 \\
\hline
\end{tabular}

Table 2. Comparison between salm3/4 and invA genes in detection of Salmonella spp from foods

\begin{tabular}{lllll}
\hline & Sensitivity & Specificity & PPV & NPV \\
\hline Salm $3 / 4$ & $70(53 / 76)$ & $100(113 / 113)$ & $100(53 / 53)$ & $83(113 / 136)$ \\
Inv A & $96(73 / 76)$ & $100(113 / 113)$ & $100(73 / 73)$ & $97(113 / 116)$ \\
\hline
\end{tabular}

Culture is taken as the gold standard

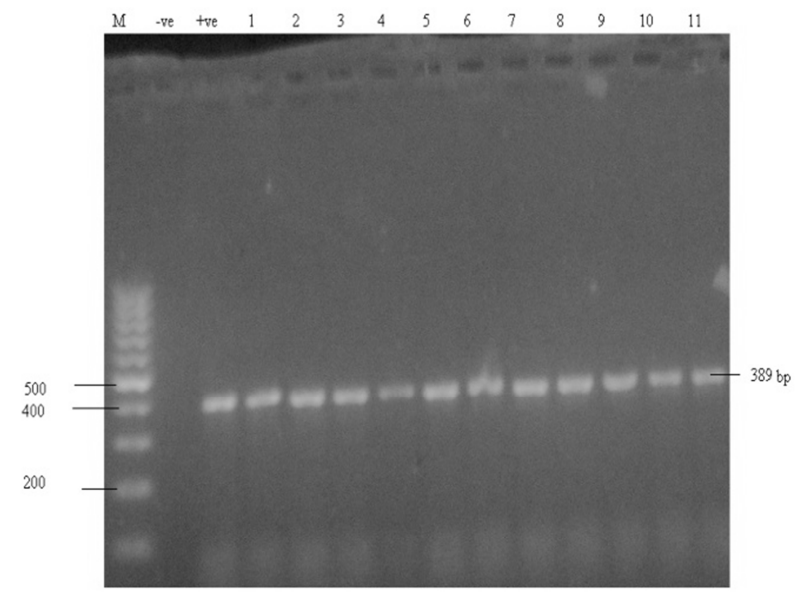

Fig 1. PCR amplification of invA genes of Salmonella spp using salm 3 and salm4 gene primer Lanes M: 100 bp ladder; Lanes 1-11 PCR products (389 bp) of salm3/4 from Salmonella spp, lane-ve and +ve is the negative and positive controls respectively.

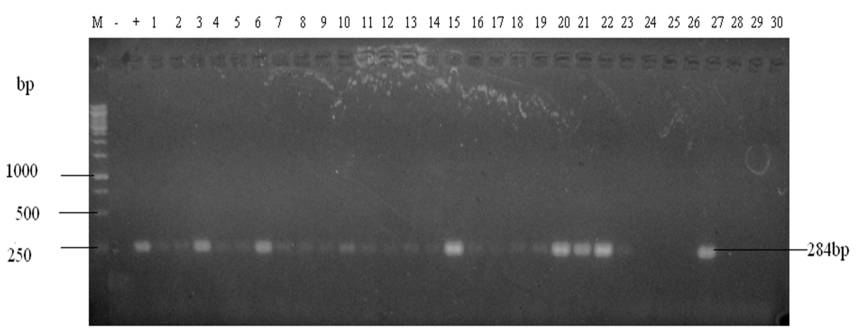

Fig 2. PCR amplification of invA genes of Salmonella spp using invA primers Lanes M: 100 bp ladder; Lanes 1-30 PCR products (284 bp) of invA primers from Salmonella spp, lane - and + is the negative and positive controls respectively. Some lanes show no amplification and were negative for this gene $(24-26)$.

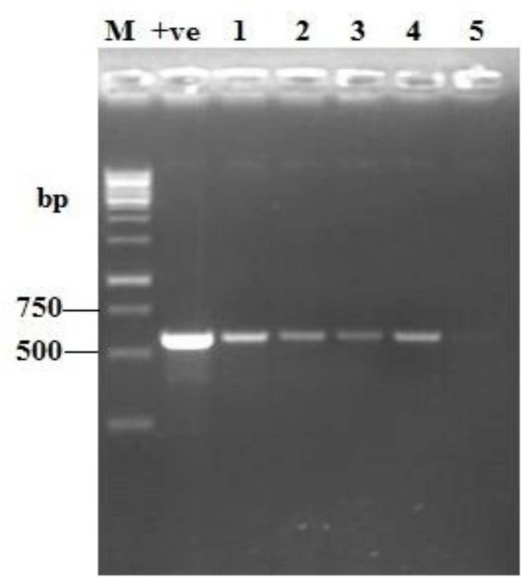

Fig 3. PCR amplification products of 574-bp DNA of 16Sr RNA gene of Salmonella spp. Lane $M=1 \mathrm{~kb}$ ladder, Lane (+) = positive control, Lane 5(-) =Negative, 1-4 positive.

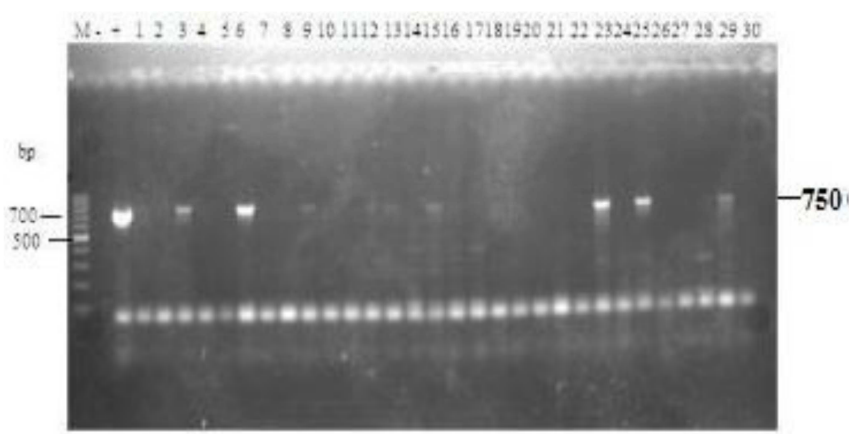

Fig 4. PCR amplification products of 750-bp DNA fragment of the sitC gene in Salmonella spp from food samples .Lane $M=100$ base pair marker, Lane $-=$ negative control, Lane $+=$ positive control 


\section{Discussion}

The prevalence of the virulence gene invA from Salmonella spp in food samples presents a public health risks and often times result to food industry losses. The detection of Salmonella spp in the developing countries is usually difficult involving cultivation and identification of the organism from humans, food samples and environmental samples. The traditional cultural methods of isolating Salmonella spp are usually time consuming and laborious. Until recently researchers tried to establish a more rapid method, which could reduce the man-hours of Salmonella identification procedures from different ranges of samples. The use of primer set inv $\mathrm{A} / i n v \mathrm{E}$ for confirmation of isolated Salmonella spp from turkeys came as relief from time waste on this identification procedures $(14,15)$. This effort was followed by the proposal of Ferretti et al. (16) for rapid detection method of Salmonella serotypes from samples within 12 hours using primers salm3andsalm 4 and invA gene. The Salmonella invA gene codes for the protein in the inner membrane which helps the organism to invade the host epithelial cell. The invA gene contains sequences unique to Salmonella spp and has proved appropriate for specific targets in various diagnostic and research laboratories (17). The use of Salmonella specific PCR with primers invA is rapid, sensitive and more specific for detection of Salmonella in many food samples. The amplification of invA gene has been validated as a standard for detection of invasion gene from Salmonella spp (12).

This study involves the use of PCR virulence genes which amplifies a $389 \mathrm{bp}$ fragment within the conserved invA gene (salm3and salm 4) of Salmonella spp as well as invA that amplifies $284 \mathrm{bp}$ to confirm the virulence and presence of Salmonella spp isolated from food samples. The results of the PCR on invA genes showed that the primer set invAF and invAR that amplified 284 bp fragment (96.1\%) was more discriminatory than the salm 3 and salm 4 primer set that amplified the $389 \mathrm{bp}$ (69.7\%) fragment and the invA gene was more sensitive than salm $3 / 4$ as well as its ability to detect more negative results in comparison to the latter, although both showed $100 \%$ PPV and specificity. A recent study from Korea had the same prevalence with the invA gene (284 bp) of $96 \%$ (18), but their prevalence with sitC genes differed as they had higher prevalence of $96 \%$ compared to ours of $50 \%$. Our result supports the ability of the two primer sets ( $\mathrm{salm}$ 3/salm 4 and invA) to confirm the presence of virulence gene in Salmonella spp. Although the salm 3 and salm 4 primer set has been suggested to be useful for direct detection of Salmonella spp as well as excellent correlation with the conventional method (16) our results do not confirm that. Our findings however suggest that the primers are specific for detection of Salmonella spp, but invA and invA primers was found to be more sensitive (96.1\%) compared to salm3 and salm4 (Table1) in the detection of Salmonella spp which corroborates the earlier reported study $(19,20)$. Our report with invA gene (284bp) was also corroborated by a recent study from Nigeria on Salmonella spp isolated from cow raw milk and milk products in which invA (284 bp) was prevalent in $100 \%$ of their isolates (21). This means that the use of invA gene (host invasion) can greatly reduce the reports of false-negative experienced in most laboratories (22). In monitoring some virulence genes such as those that code for iron transport (sitC) and the Salmonella virulence plasmids $(s p v \mathrm{~A}, s p v \mathrm{~B}$ and $s p v \mathrm{C})$, our results showed that whereas half of the isolates encode genes for iron transport, none of our isolates carried the $s p v \mathrm{~A}, s p v \mathrm{~B}$ and $s p v \mathrm{C}$ genes. This report corroborated with arlier the study (23) in which invA, sef genes were detected in their isolates from butcher shops in Brazil, and none of the isolates carried the $s p v \mathrm{C}$ gene. To further corroborate the results of our study and that of Cossi et al. (23), 17 virulence genes were studied including sitC, $i n v \mathrm{~A}$ and $s p v \mathrm{~B}$, none were positive for $s p v \mathrm{~B}$ in both food and environmental isolates (24). In a related study out of 17 virulence genes tested, 14 Salmonella isolates were positive with the exception of $s p v \mathrm{~B}, c d t \mathrm{~B}$ and pef $\mathrm{A}$ of which pef $\mathrm{A}$ and $s p v \mathrm{~B}$ were plasmid encoded (25). However, from this study only the $s p v \mathrm{~B}$, pefA had lower prevalence $(5 \%$ and $3.75 \%$ respectively) while other more common ones such as the invA had $100 \%$ prevalence (13). This suggests the possibility that our local food isolates studied did not have virulence genes ( $s p v \mathrm{~A}, s p v \mathrm{~B}$ and $s p v \mathrm{C})$ located on the plasmids but could be chromosomally located as the latter three genes are for Salmonella virulence plasmids. The other possibility could be due to the fact that not all isolates contain virulence plasmids as lower proportions were reported in some reports for the plasmid virulence genes $(26,27,13,18)$. In contrast Amini et al. (8) reported that the $s p v$ genes were prevalent in $88.6 \%$ for poultry, $90 \%$ for humans and $100 \%$ for bovine, although all isolates were S. Enteritidis, while other study reported moderate prevalence $(42.85 \%)$ of the $s p v \mathrm{C}$ gene in their commercial food stuffs (28). However, other reports have confirmed the ubiquitous distribution of virulence genes amongst Salmonella spp irrespective of the host (25). The PCR method using target gene remains a suitable molecular tool to diagnose Salmonella in human, animal and plant products $(8,19)$. These findings have important health implications to the entire populace considering the high prevalence of virulence genes in food samples studied and it also underscores the need for rapid identification of Salmonella virulence genes using the PCR method.

In conclusion, most of our food isolates harbored invA virulence gene and this has its economic and public significance for the country. Consequently, it is necessary to consider food hygiene programs to prevent health hazards and economic loss due to increasing morbidity and mortality associated with salmonellosis with possible antibiotic resistance. Rapid detection of Salmonella spp by PCR of invA genes is recommended, although all our isolates did not harbor the $s p v$ genes. Further analysis on accurate distribution of virulence genes is important to help us develop accurate preventive measures against Salmonella spp in Nigeria. 


\section{Abbreviations}

NTS: Non Typhoidal Salmonella, invA: invasion gene A, sitC: salmonella iron transport, spv: Salmonella plasmid virulence, salm: Salmonella, pefA: plasmid encoded fimbriae A

\section{Acknowledgements}

This study was funded by International Foundation for Science (IFS) grant noE/4020- given to SIS.

\section{References}

[1] Alvarez, A. M. Integrated approaches for detection of plant pathogenic bacteria and diagnosis of bacterial diseases. Ann. Rev. Phytopath. 42: 339-366. 2004.

[2] Amini, K., Salehi, T. Z., Nikbakht, G., Ranjbar, R., Amini, J and Ashrafganjooei, S. B. Molecular detection of invA and $s p v$ virulence genes in Salmonella enteritidis isolated from humans and animals in Iran. Afr. J. Microbiol. Res. 4: 2202 2210. 2010.

[3] Bennett, A. R., Greenwood, D., Tennant, C., Banks, J. G and Betts, R. P. Rapid and definitive detection of Salmonella in foods by PCR. Lett. Appl. Microbiol. 26:437-441. 1998.

[4] Chiu, C. H., Wu, T. L., Su, L. H., Chu, C., Chia, J. H., Kuo, A J., Chien, M. S and Lin, T. Y. The emergence in Taiwan of fluoroquinolone resistance in Salmonella enterica serotype Choleraesuis. N. Eng. J. Med. 346: 413-419. 2002.

[5] Chiu, C.H. and Ou, J.T. Rapid identification of Salmonella serovars in faeces by specific detection of virulence genes, $i n v \mathrm{~A}$ and $s p v \mathrm{C}$, by an enrichment broth-multiplex PCR combination assay. J. Clin. Microbiol. 34: 2619 -2622. 1996.

[6] Cossi, M. V., Burin, R.C., Lopes, D.A., Dias, M. R., Castilho, N.P., de ArrudaPinto P. S. and Nero L. A. Antimicrobial resistance and virulence profiles of Salmonella isolated from butcher shops in Minas Gerais, Brasil. J. Food Prot. 76: 16331637. 2013.

[7] Darwin, K. H. and Miller V.L. Molecular basis of the interaction of Salmonella with the intestinal mucosa. Clin. J. Microbiol. 12: 405-428. 1999.

[8] Das, A., Hari, S. S., Shalini, U., Ganeshkumar, A. and Karthikeyan, M. Molecular Screening of Virulence Genes from Salmonella enterica Isolated from Commercial Food Stuffs. Biosciences Biotechnology Res. 9: 363-369. 2012

[9] Das, S., Singh, S., McClelland, M., Forst, S. and Gyaneshwar, P. Characterization of an Acid-Inducible Sulfatase in Salmonella enteric Serovar Typhimurium. Appl. Environ. Microbiol.79: 03707-03712. 2013.

[10] Dione, M. M., Ikmapayi, U., Saha, D., Mohammed, I. N., Adegbola, A. R., Geerts, S., Leven, M and Antonio, M. Antimicrobial resistance and virulence genes of non-typhoidal Salmonella isolates in the Gambia and Senegal. J. Infect. Dev. Ctries. 5: 765-775. 2011.

[11] Dorji, T.M., Mamata, G., Hyang-Mi, N., Chan, M.D., SukChan. J. and Suk-Kyung, L. Antimicrobial susceptibility and virulence characteristics of Salmonella enteric Typhimurium isolates from healthy and diseased pigs in Korea. J. Food Prot. 9: $1481-1486.2014$
[12] Ferretti, R., Mannazzu, L., Cocolin, L., Comi, G. and Clementi, F. Twelve-hour PCR-based method for detection of Salmonella spp in food. Appl. Environ. Microbiol. 74: 977978. 2001.

[13] Gorman, R., Bloomfield, S. and Adley, C. C. A study of crosscontamination of food-borne pathogens in the domestic kitchen in the Republic of Ireland. Int. J. Food Microbiol.76: 143-50. 2000.

[14] Guo, L., Killfer, J., Kenny, P. B. and Amick-Morri, J. D. Use of arbitrarily primed Polymerase chain reaction to study Salmonella ecology in a turkey production. Environ. Poult Sc.78: 24-31. 1999.

[15] Karmi, M. Detection of virulence genes (invA) in Salmonella isolated from Meat and Poultry Products. Int. J. Genetics 3: 712. 2013.

[16] Li, Q., Skyberg, .J A., Fakhr, M. K., Sherwood, J.S., Molan, L.K. and Logue, C.M. Antimicrobial susceptibility and characterization of Salmonella isolates from processed Bison Carcasses. Appl Environ Microbiol 72: 3046- 3049. 2006.

[17] Malorny, B., Hoorfar, J., Bunge, C. and Helmuth, R. Multicenter validation of the analytical accuracy of Salmonella PCR: towards an international standard. App. Environ. Microbiol. 69: 290-296. 2003.

[18] Mezal, E. H., Stefanova, R. and Khan, A.A. Isolation and molecular characterization of Salmonella enterica serovar Javiana from food, environmental and clinical samples. Int. J. Food Microbiol. 164: 113 -118. 2013.

[19] Oluduro, A. O., Thonda, O.A. and Kolawole, D.O. Phenotypic and Molecular Characterization of Salmonella serotypes in cow milk and milk products in Nigeria. Afr. J. Biotechnology 13: 3774 -3789. 2014.

[20] Pan, T. M. and Liu, Y. J. Identification of Salmonella enteritidis isolates by polymerase chain reaction and multiplex polymerase chain reaction. J. Microbiol. Immun. Infect. 35: 147-151. 2002.

[21] Ramya, P., Madhavarao, T. and Rao, L. V. Study on the incidence of Salmonella enteritidis in poultry and meat samples by cultural and PCR methods. Vet. World5: 541-545. 2012.

[22] Salehi, T. Z., Mahzounieh, M. and Saeedzadeh, A. Detection of InvA Gene in Isolated Salmonella from Broilers by PCR Method. Int. J. Poultry Sc. 4: 8, 557-559. 2005.

[23] Schneder, A., Gronewald, C., Fandke, M., Kurth, B., Barkowski, S. and Berghof-ager, K. Real-time detection of the genus Salmonella with the Light Cycler system. Biochem. J. 4: 19-21. 2002.

[24] Skyberg, J.A., Logue, C.M. and Nolan, L.K. Virulence genotyping of Salmonella spp with multiplex PCR. Avian Dis. 50: 77-81. 2006.

[25] Smith, S. 1., Opere, B., Fowora, M., Aderohunmu, A., Ibrahim, R., Omonigbehin, E., Bamidele, M. and Adeneye, A. Molecular characterization of Salmonella spp directly from snack and food commonly sold in Lagos, Nigeria. Southeast Asian J. Trop. Med. 43: 718-23. 2012.

[26] Swamy, S.C., Barnhart. H., Lee, M.D. and Dreesen, D.W. Virulence determinants $i n v \mathrm{~A}$ and $s p v \mathrm{C}$ in salmonellae isolated from poultry products, wastewater and human sources. Appl. Environ. Microbiol. 62: 3768 -3771. 1996. 
[27] Todd, E. C. D., Greig, J. D., Bartleson, C. A and Michaels, B. S. Outbreaks where food workers have been implicated in the spread of foodborne disease. Part 4. Infective doses and pathogen carriage. J. Food Prot. 71: 2339-2373. 2008.
[28] Van den Bogaard, A. E and Stobberingh, E. E. Epidemiology of resistance to antibiotics. Links between animals and humans. Int. J. Antimicrob. Agents14: 327-35. 2000. 